Portland State University

PDXScholar

Civil and Environmental Engineering Faculty

Publications and Presentations

Civil and Environmental Engineering

$12-2-2014$

\title{
Ensemble Prediction and Data Assimilation for Operational Hydrology
}

\author{
Dong-Jun Seo \\ University of Texas at Arlington \\ Yuqiong Liu \\ NASA Goddard Space Flight Center \\ Hamid Moradkhani \\ Portland State University, hamidm@pdx.edu \\ Albrecht Weerts \\ Wageningen University
}

Follow this and additional works at: https://pdxscholar.library.pdx.edu/cengin_fac

Part of the Categorical Data Analysis Commons, Hydrology Commons, and the Meteorology

Commons

Let us know how access to this document benefits you.

\section{Citation Details}

Seo, D., Liu, Y., Moradkhani, H., \& Weerts, A. (2014). Ensemble prediction and data assimilation for operational hydrology. Journal Of Hydrology, 5192661-2662. doi:10.1016/j.jhydrol.2014.11.035

This Editorial is brought to you for free and open access. It has been accepted for inclusion in Civil and Environmental Engineering Faculty Publications and Presentations by an authorized administrator of PDXScholar. Please contact us if we can make this document more accessible: pdxscholar@pdx.edu. 
Editorial

\section{Ensemble prediction and data assimilation for operational hydrology}

Ensemble methodologies are fast gaining popularity and acceptance as a new paradigm for operational hydrologic forecasting and risk-based water resources management. This trend reflects the recognition that there will always be significant uncertainties in hydrologic predictions due to limited predictability in atmospheric forcings, errors in model structures, initial condition, parameters and states, and unknown/unknowable human control of the hydrologic cycle (Krzysztofowicz, 1999; Seo et al., 2006; Liu and Gupta, 2007; Todini, 2008; Weerts et al., 2011; DeChant and Moradkhani, 2011; Madadgar et al., 2014), that quantification of source-specific uncertainty affords cost-effective improvement of the forecast system and process (Demargne et al. 2014; Verkade et al., 2013; Moradkhani et al., 2012), and that ensemble approaches allow objective utilization of multiple sources of data and models that are very often complementary (Georgakakos et al. 2004; Parrish et al., 2012).

In uncertainty modeling of complex hydrologic processes and water management practices, real-world applications of ensemble techniques present a number of significant scientific challenges (Hartman, 2007): modeling and integration of uncertainties associated with data, model, and human control, producing ensemble forcings for short to long ranges from multiple sources that are dynamically and statistically consistent across a wide range of space-time scales, providing uncertainty and verification information in a form and context that is easily understandable and useful to the users, reducing uncertainty in both meteorological and hydrologic models, and improving uncertainty modeling and observations of rare and extreme events such as floods and droughts. The above list illustrates that, to advance hydrologic ensemble prediction in operational hydrology, advances are necessary in many elements in the ensemble forecast system.

A salient bottleneck in operationalization of hydrologic ensemble prediction is data assimilation (DA). In operational forecasting, the observed forcings and model states are routinely adjusted, often in a manual fashion, to keep the model simulation in line with observed streamflow. Such a practice, however, is not viable in ensemble forecasting as it is impractical, if not infeasible, to adjust high-order moments manually. While the development and application of modern DA techniques in hydrology (Kitanidis and Bras, 1978) predates popularization of DA in oceanography and weather forecasting, automatic DA in operational hydrology remains a large challenge due to multiscale nature of the hydrologic processes and under-determinedness of most hydrologic systems. In reality, the basic assumptions that the standard DA techniques require are seldom met (Liu et al., 2012). To operationalize automatic DA in ensemble forecasting, advances in DA science are necessary which may include new, less restrictive approaches.
Both the science of hydrologic ensemble prediction and its community are fast growing. Given the ever-increasing computing power and communication capabilities, and availability of data, it seems obvious that ensemble approaches will propagate to all practices of forecasting and managing water. Toward that end, advances are necessary in many elements of ensemble prediction, of which effective, efficient and robust methodologies for DA are a prime example. Through close interactions among the research, operational and user communities, new ideas and innovations are constantly put to the test in hydrologic ensemble prediction and DA. The purpose of this special issue is to share in a timely manner the latest advances, lessons learned, experiences gained, and science issues and challenges in the context of advancing operational hydrology and water resources management. The topics covered are as follows where the relevant contributions are identified in parentheses:

- Improving hydrologic forecasting and water resources management by assimilating observations of streamflow, soil moisture, snow, and rainfall (Thirel et al., Abaza et al., Franz et al., Renzullo et al., Alvarez-Garreton et al.).

- Advances in theoretical and mathematical aspects of hydrologic DA and their applications (Noh et al., Rafieeinasab et al., Ryu et al., Yoo et al.).

- Applications of hydrologic DA in water quality forecasting (Kim et al., Park et al.).

- Post-processing of hydrometeorological and hydrologic forecasts, and its interactions with DA (Bourgin et al., Zhou et al., Schepen et al.).

- Hydrologic ensemble forecasting and DA for uncertainty quantification (Bennett et al., Fan et al., DeChant and Moradkhani).

- Evaluation of ensemble hydrologic forecasts of precipitation, temperature and streamflow (Brown et al., Brown et al., Duan et al., Mehrotra et al., K. Georgakakos et al.).

- Accounting for water use and regulations in hydrologic ensemble forecasting (A. Georgakakos et al.).

The overarching aim of the articles published in this special issue is to engage a diverse audience and stimulate further discussions on advancing hydrologic ensemble prediction and DA, including on those important topics that are not extensively covered in the current issue, such as the forecasting of extreme hydrologic events (floods and droughts), and the practical and beneficial use of satellite-based observations in operational streamflow forecasting. We are hopeful that the Special Issue will benefit the interested readers including the stakeholders, and spur and accelerate advances in the relevant areas. 
Finally, the Guest Editors would like to gratefully acknowledge the authors for their contributions and patience, the many reviewers for their time and effort, the Chief Editor, Dr. Konstantine Georgakakos, for orchestrating the overall review process, and the editorial staff of the Journal for administrative and logistical support throughout the process.

\section{References}

DeChant, C., Moradkhani, H., 2011. Improving the characterization of initial condition for ensemble streamflow prediction using data assimilation. Hydrol. Earth Syst. Sci. 15, 3399-3410. http://dx.doi.org/10.5194/hess-15-3399.

Demargne, J., Wu, L., Regonda, S., Brown, J., Lee, H., He, M., Seo, D.-J., Hartman, R., Herr, H., Fresch, M., Schaake, J., Zhu, Y., 2014. The science of NOAA's operational hydrologic ensemble forecast service. Bull. Am. Meteorol. Soc.. http:// dx.doi.org/10.1175/BAMS-D-12-00081.1.

Hartman, R., 2007. Progress toward the development and application of ensemblebased short-term hydrologic forecasts. In: H52A-05 2007 AGU Fall Meeting, San Francisco, CA.

Georgakakos, K., Seo, D.-J., Gupta, H., Schaake, J., Butts, M.B., 2004. Towards the characterization of streamflow simulation uncertainty through multimodel ensembles. J. Hydrol. 298 (1-4), 222-241 (DMIP special issue).

Kitanidis, P.K., Bras, R.L., 1978. Real Time Forecasting of River Flows. Ralph M. Parsons Laboratory for Water Resources and Hydrodynamics, Dept of Civil Engineering, MIT TR235.

Krzysztofowicz, R., 1999. Bayesian theory of probabilistic forecasting via deterministic hydrologicmodel. Water Resour. Res. 35 (8), 2739-2750.

Liu, Y., Gupta, H.V., 2007. Uncertainty in hydrologic modeling: toward an integrated data assimilation framework. Water Resour. Res. 43, W07401. http://dx.doi.org/ 10.1029/2006WR005756.

Liu, Y., Weerts, A.H., Clark, M., Hendricks Franssen, H.-J., Kumar, S., Moradkhani, H., Seo, D.-J., Schwanenberg, D., Smith, P.J., van Dijk, A.I.J.M., van Velzen, N., He, M., Lee, H., Noh, S.J., Rakovec, O., Restrepo, P., 2012. Advancing data assimilation in operational hydrologic forecasting: progresses, challenges, and emerging opportunities. Hydrol. Earth Syst. Sci. 16, 3863-3887. http://dx.doi.org/ 10.5194/hess-16-3863-2012.

Madadgar, S., Moradkhani, H., Garen, D., 2014. Towards improved post-processing of hydrologic forecast ensembles. Hydrol. Process. 28 (1), 104-122. http:/ dx.doi.org/10.1002/hyp.9562.

Moradkhani, H., DeChant, C.M., Sorooshian, S., 2012. Evolution of ensemble data assimilation for uncertainty quantification using the particle filter-markov chain Monte Carlo method. Water Resour. Res. 48, W12520. http://dx.doi.org/ 10.1029/2012WR012144.

Parrish, M., Moradkhani, H., DeChant, C.M., 2012. Towards reduction of model uncertainty: integration of bayesian model averaging and data assimilation. Water Resour. Res. 48, W03519. http://dx.doi.org/10.1029/2011WR011116.
Seo, D.-J., Herr, H., Schaake, J., 2006. A statistical post-processor for accounting of hydrologic uncertainty in short-range ensemble streamflow prediction. Hydrol. Earth Syst. Sci. Discuss. 3, 1987-2035.

Todini, E., 2008. A model conditional processor to assess predictive uncertainty in flood forecasting. Intl. J. River Basin Manage. 6 (2), 123-137.

Verkade, J.S., Brown, J., Reggiani, P., Weerts, A.H., 2013. Post-processing ECMWF precipitation and temperature ensemble reforecasts for operational hydrologic forecasting at various spatial scales. J. Hydrol. 501, 73-91. http://dx.doi.org/ 10.1016/j.jhydrol.2013.07.039.

Weerts, A.H., Winsemius, H.C., Verkade, J.S., 2011. Estimation of predictive hydrological uncertainty using quantile regression: examples from the National Flood Forecasting System (England and Wales). Hydrol. Earth Syst. Sci. 15, 255-265. http://dx.doi.org/10.5194/hess-15-255-2011.

Guest Editors

Dong-Jun Seo

Department of Civil Engineering, The University of Texas at Arlington, Box 19308, Rm 248E Nedderman Hall, 416 Yates St, Arlington, TX 76019-0308, USA

E-mail address: djseo@uta.edu URL: http://www.uta.edu/ce/research/hwrl/index.php

Yuqiong Liu

NASA Goddard Space Flight Center, Hydrologic Sciences Laboratory, Code 617, 8800 Greenbelt Rd, Greenbelt, MD 20771, USA E-mail address: yuqiong.liu@nasa.gov

Hamid Moradkhani

Department of Civil Engineering, Portland State University, 1930 SW 4th Ave., suite 200, Portland, OR 97201, USA

E-mail address: hamidm@pdx.edu URL: http://web.cecs.pdx.edu/ hamidm/

Albrecht Weerts

Deltares, PO Box 177, 2600 MH Delft, The Netherlands

Hydrology and Quantitative Water Management Group, Department of Environmental Sciences, Wageningen University, The Netherlands E-mail addresses: albrecht.weerts@deltares.nl, albrecht.weerts@wur.nl 